\title{
A ECONOMIA POLIITICA DOS BACHARÉIS UDENISTAS
}

\author{
Jorge Gomes de Souza Chaloub \\ Fundação Getúlio Vargas (FGV), Rio de Janeiro - RJ, Brasil. E-mail: jchaloub84@gmail.com
}

DOI: $10.17666 / 329406 / 2017$

\section{Introdução}

A União Democrática Nacional (UDN) nasce marcada por grandes tensóes internas, devidamente conservadas ao longo da sua existência e amparadas em diversos ideários e visóes de mundo. $\mathrm{O}$ terreno econômico é particularmente exemplar nesse sentido. Durante a República de 1946, o partido abrigou distintas perspectivas acerca da organizaçáo e do funcionamento da economia, as quais impedem que se possa falar em algo semelhante a uma diretriz econômica estável.

Maria Victoria Benevides vê em tal diversidade a ausência de uma diretriz econômica mais forte do partido. A economia revelaria de forma privilegiada, na visão da autora, as ambiguidades e contradiçóes que marcam o liberalismo udenista:

Artigo recebido em 23/08/2016

Aprovado em 18/11/2016
O exame da política econômica da UDN revela, talvez com maior nitidez, a inconsistência programática e as contradições partidárias. A posiçáo do partido resultava, muitas vezes, do esforço ou interesse isolado de um udenista que encampava uma questão específica [...] A UDN não defendia um 'modelo econômico' pois seu programa era fundamentalmente inspirado pelos aspectos políticos de cada questão, negligenciando os aspectos técnicos da realidade econômica financeira (Benevides, 1981, p. 196)

O assunto também desvela as mazelas do bacharelismo, outro tema da obra de Benevides, as quais impediriam, com seu gosto pelas ideias gerais, o aprofundamento na expertise técnica fundamental para a adequada compreensão das dinâmicas econômicas: "É nesse campo que a influência do bacharelismo ${ }^{1}$ se fará mais decisiva; os professores de finanças da UDN também se apresentariam marca- 
dos pelo juridicismo, por orientação teórica muitas vezes desvinculada das questóes eminentemente práticas" (Benevides, 1981, p. 196). A autora aponta, com grande pertinência, que os grandes protagonistas da atuação udenista nos temas econômicos formuladores dos programas partidários e representantes do partido nos embates públicos - não eram os economistas, no sentido contemporâneo da expressão, mas "os titulares das Faculdades de Direito (cadeiras de Economia Política e Ciências das Finanças)" (Idem, p. 197). Em virtude da sua origem, os atores não escapariam dos males do bacharelismo, que se faziam ainda mais exacerbados num terreno em que os bacharéis desconheciam os debates mais modernos. Nesse cenário, personagens como Bilac Pinto e Aliomar Baleeiro acabariam enredados em velhos preconceitos inspirados pelo "ensino excessivamente verbalista nas Faculdades de Direito" (Idem, ibidem) e limitados por uma "concepção manchesteriana da economia e das finanças - sem ter ainda recebido o influxo das ideias keynesianas" (Idem, ibidem). ${ }^{2}$

O presente artigo segue, todavia, caminho diverso. Onde Maria Victoria Benevides vê uma série de pressupostos arcaicos submetidos à lógica contingente da utilidade, com a economia completamente dominada pelos imperativos da política mais imediata, creio ser possível identificar uma feição diversa. A chave para tal esforço está justamente no bacharelismo, que desvela os fundamentos de uma visão de mundo mais coerente no campo econômico. Para tanto, deve-se olhar para o lugar da economia no liberalismo dos bacharéis. Não se trata, como é evidente, de uma plena coerência, esta mais adequada aos esforços teóricos do que aos partidos políticos, mas de uma prática que não se resume à sequência desordenada de açóes individuais, organizando-se de forma relativamente estável e longeva.

O texto aborda, inicialmente, as principais características e pontos de convergência das concepçóes econômicas cultivadas pelos bacharéis udenistas, seja em meio a reflexóes teóricas ou a discursos políticos. Posteriormente, são dedicadas seçóes àqueles com mais ampla contribuição no tema: Afonso Arinos de Melo Franco, Aliomar Baleeiro e Bilac Pinto. Faz-se, por fim, uma breve aproximação entre a economia política dos referidos bacharéis e as perspectivas en- tâo defendidas por Roberto Campos, um dos mais influentes economistas do período.

\section{A economia política dos bacharéis}

A recepção das ideias econômicas nas arenas político-institucionais não era simples ao longo da República de 1946. Para além das usuais mediaçóes entre as formulações intelectuais e a prática política, havia o peculiar lugar do discurso econômico, que estava distante do maior prestígio que ganharia algumas décadas depois e se encontrava pulverizado entre muitos personagens - como bacharéis e engenheiros -, já que a figura do economista ganhava tons ainda imprecisos num cenário em que eram escassos os cursos de graduação especializada. A época, entretanto, era de transiçấo, marcada pela crescente importância dos argumentos econômicos e da própria figura do economista. Se ainda estava distante da grande hegemonia posterior, é inegável que a economia crescia em prestígio em relação a um passado próximo e passava a ocupar lugar fundamental na esfera pública. Pode-se mesmo falar, analogamente à formulação de Antonio Candido em Formação da literatura brasileira, que estamos diante do período de formação do pensamento econômico brasileiro, a partir da crescente densidade da discussão econômica e da clara construção de um complexa rede de autores e leitores. Os atores que assumiam a persona de economistas, por sua vez, também ganhavam crescente espaço no debate intelectual e no Estado, com tal destaque justificado por sua expertise técnica na "ciência econômica". Foi na qualidade de técnicos do Estado ou de instituiçóes de pesquisa que figuras como Eugênio Gudin Filho, Roberto Campos, Celso Furtado e Rômulo Almeida se afirmaram no cenário público e exerceram fundamental influência nos rumos do país.

O momento, todavia, ainda dava enorme destaque a outras formas de discurso sobre a economia, que conviviam e disputavam o debate público. Os bacharéis, por exemplo, especialmente os catedráticos de disciplinas vinculadas às finanças públicas, traziam outros argumentos e perspectivas que, mesmo muitas vezes menos elaborados e sistemáticos que os dos expoentes do pensamento econômico 
citados, se beneficiavam de uma articulação política mais eficiente. Um fato fundamental nesse eventual embate era que, mesmo alocados em relevantes órgãos estatais e internacionais - como a Organização das Naçóes Unidas (ONU), o Banco Nacional de Desenvolvimento Econômico (BNDE), a Assessoria Econômica da Presidência, a Comissão Mista Brasil-Estados Unidos, entre outros -, os economistas náo tinham grande influência dentro dos partidos políticos, instituiçóes fundamentais para a disputa pelo poder. É claro que eles desenvolveram certa proximidade e afinidade com determinadas legendas, às quais eram muitas vezes filiados, mas isso não lhes garantia um papel central em boa parte dos processos decisórios internos, em que quase sempre acabavam suplantados pelos políticos de perfil mais tradicional. Havia, ademais, mesmo as limitaçóes da construção das suas personas públicas: afinal, está-se diante de economistas, não de políticos. Desse modo, ainda que influentes para os rumos do cenário político, os economistas dependiam de disputas nas quais eles tinham menor influência e acabavam limitados na capacidade de transformar suas formulações intelectuais em políticas públicas, assim como se viam muitas vezes suplantados por políticos, quando os temas econômicos ultrapassavam o debate restrito dos especialistas e alcançavam as grandes arenas públicas.

Esse cenário, descrito em breves palavras, ajuda a explicar alguns encontros e desencontros, pouco evidentes à primeira vista, entre os ideários econômicos e as ideologias políticas que, à primeira vista, poderiam lhes parecer mais próximas. Um exemplo é a distância que por vezes se percebia entre o liberalismo no debate econômico, representado por Gudin e Bulhôes, e o principal partido liberal da época: a União Democrática Nacional (UDN). As dissonâncias se revelam, sobretudo, no campo intelectual, com uma análise mais apurada a revelar duas distintas vertentes liberais, mas esses tipos de discurso não deixam de influenciar a posição dos atores em importantes questôes do debate público.

O liberalismo conservador - marca de bacharéis como Arinos, Milton Campos e Prado Kelly não via o indivíduo moderno, guiado apenas pela busca dos seus interesses, como base da organização social. A inspiração utilitária cedia lugar à busca de uma ordem harmônica, amparada em valores qualitativamente superiores. A organização social e política era construída a partir do Estado, que tinha no direito elemento privilegiado para essa tarefa, e não do mercado, com seu mecanismo de transformar os vícios privados do indivíduo utilitário em virtudes públicas. $\mathrm{O}$ puro interesse não seria o mais importante critério de organização do mundo social, mas deveria ser submetido a razóes maiores, como a virtude, ou filtrado por um olhar que ultrapassa os ganhos individuais imediatos, aos moldes do "interesse bem compreendido" de Tocqueville (2001). As virtudes públicas dependeriam da boa qualidade dos homens - em chave de claro teor aristocrático -, não de mecanismos impessoais de produção de regularidades. Justamente por isso, para os bacharéis, a presença de verdadeiros líderes, os "estadistas" na terminologia de Arinos, era fundamental para o bom andamento da sociedade, que padeceria quando submetida aos falsos governantes, os caudilhos. A justificava para essa opção se fundava parcialmente em visóes de mundo com aspirações de universalidade, como se percebe na firme crítica de Milton Campos a um mundo desencantado, que reduz tudo ao aspecto quantitativo e ao puro interesse: "Porque não será republicano considerarmos a Pátria uma sociedade anônima, o governo uma gerência, a política um negócio e a imprensa uma empresa" (Campos, 1972, p. 110). Tal perspectiva convivia, entretanto, com análises sobre as especificidades da formação brasileira, que seguiria caminhos distantes do mercado, em percurso distinto do americano, como frequentemente argumentava Arinos:

Ocorre, porém, Sr. Presidente, que a nossa formação e a nossa conjuntura atual são particularmente diversas das que se verificam na grande república do norte. Os EUA são, por excelência, uma nação capitalista, uma nação que surgiu com o capitalismo, em função do capitalismo e por causa do capitalismo. [...] O Brasil, com uma formação completa diversa, Sr. Presidente, está ainda longe de ser um país capitalista. [...] A verdade é que os usos mais fecundos do nosso passado demonstram, Sr. Presidente, que melhor andou gerida a coisa 
pública nos setores entregues aos problemas financeiros e econômicos, quando os gestores dessa coisa pública não eram pessoalmente os representantes [...] das grandes forças econômicas da empresa privada (Franco, 1953).

A interpretação de que o país ainda estava distante do pleno funcionamento da ordem capitalista não incentivava propostas de construção da ordem a partir do mercado, visto como incapaz de se impor como força hegemônica. Afirma-se, então, um tipo particular de liberalismo, em que os traços e valores aristocráticos predominam sobre o esforço pela construçáo de uma ordem burguesa. O papel dos bacharéis é central nessa empreitada, com o direito a desempenhar a função de principal linguagem da sua prática e reflexão política. Se os argumentos jurídicos perpassam a reflexão do partido sobre as mais diversas áreas, há que se ressaltar que o direito não era visto como técnica fechada em si mesma, mas como arte do bem administrar a sociedade, sem, contudo, em nenhum momento dela se apartar.

O liberalismo modernizante, por sua vez, típico de bacharéis como Bilac Pinto e Aliomar Baleeiro, adotava perspectiva similar ante a relação entre o mercado e o Estado, mas assumia tom menos aristocrático e elogioso perante o passado. A exclusiva direção da economia pelo mercado não se adequava aos novos tempos, em que muitas vezes se atribuía ao Estado, sobretudo em questóes relevantes, o protagonismo na condução da sociedade. $\mathrm{O}$ direito ainda é visto como instrumento político de organização social, mas há menor destaque à virtude dos governantes e maior preocupação em modernizar o aparato jurídico e o Estado. O liberalismo não se define, nessa vertente, como "estado espírito", à moda de Milton Campos, mas como instrumento de controle do processo de transformação social. Dentre os pontos comuns ante a vertente liberal conservadora, permanece a perspectiva politizada da economia, que deveria se sujeitar aos ditames mais amplos e profundos do interesse coletivo.

Maria Victoria Benevides identifica com precisão a submissão da economia à política no discurso e na prática política dos bacharéis, mas não percebe o caráter mais sistemático da construção e a coerência de tal perspectiva com o liberalismo por eles propagado. Mais do que a "ausência de um modelo econômico", desenhava-se uma concepção econômica que recusava ao mundo da economia a autonomia que certo debate econômico muitas vezes o atribuía e que, com o tempo, se mostrou cada vez mais hegemônica. Os bacharéis por vezes se mostravam realmente distantes da bibliografia especializada mais contemporânea - mesmo que a conhecessem - e formavam suas concepçóes da economia a partir de uma literatura de origem frequentemente jurídica, com fortíssima presença do direito público francês e, sobretudo no caso dos modernizantes, norte-americano. Tal escolha, entretanto, não se fundava apenas na dificuldade da velha formação jurídica em conjugar os verbos mais contemporâneos, pois também expressava uma visão de mundo, marcada pela recusa da centralidade do mercado e do indivíduo moderno, centros de outros discursos liberais, e pelo elogio de uma concepção politizada da economia.

A distância entre os bacharéis e Gudin e Bulhôes, liberais de corte neoclássico, não se funda apenas nos interesses ocasionais dos personagens, mas revela distintos ideários liberais. O liberalismo econômico de Gudin, que defendia princípios econômicos universais e via no mercado o instrumento mais eficiente de organização do mundo social, mostrava-se bem diverso das ideias de figuras como Arinos, Bilac Pinto e Baleeiro, que davam ao Estado um inegável protagonismo para, pela via do direito, determinar os melhores caminhos para a dinâmica social, além de argumentarem em favor das especificidades do caso brasileiro, que náo podia demandar os mesmo remédios e soluçóes de países com formação social completamente diversa.

Havia, por certo, outras linguagens liberais na UDN, muitas delas mais afeitas ao mundo do mercado. Podemos, nesse sentido, citar tanto personagens como Clemente Mariani, Herbert Levy e Magalhães Pinto, que reivindicavam um liberalismo econômico mais clássico, como até mesmo Carlos Lacerda, que, apesar da defesa da centralidade da ação política, era mais aberto a formulaçôes entusiastas da centralidade do interesse individual. Os próprios bacharéis, em suas diversas matizes, não eram críticos radicais da lógica do capital ou refra- 
tários ao mercado; apenas defendiam que a última palavras náo deveria pertencer ao mundo da economia, mas precisava passar pelo crivo da expertise política dos estadistas. Não se trata, nesse sentido, de contradição à posição muitas vezes favorável da UDN perante o capital estrangeiro, presente tanto no forte apoio à polêmica Instruçáo 113 da Superintendência da Moeda e do Crédito (Sumoc) decretada por Gudin em seu período à frente do Ministério da Fazenda - quanto nas fortes críticas endereçadas à Lei da Remessa de Lucros, sancionada por João Goulart em 1962. O capital estrangeiro era não apenas desejado, segundo os bacharéis, mas sempre necessário, desde que limitado pelos imperativos da Razão de Estado.

O partido, por outro lado, também não traiu seus ideais quando optou, em algumas questóes, por posiçóes que contrariavam a banca internacional, como no significativo caso do Monopólio do Petróleo. É evidente que, nesse e em outros embates, motivos de ordem pragmática, impostos pela lógica do enfrentamento político, conviviam ao lado de crenças e concepçóes mais arraigadas e longevas. O cálculo utilitário é parte fundamental da dinâmica política. A escolha dos udenistas não destoava, entretanto, dos fundamentos do seu liberalismo, já que as concepções de mundo dos bacharéis eram, em muitos sentidos, coerentes com a decisão do partido. Mais do uma traição ou um falso liberalismo, estamos diante de uma diferente linguagem liberal. Mesmo Maria Victoria Benevides aponta precisamente como vários documentos programáticos e de campanha dos primeiros anos do partido admitiam e defendiam em muitos pontos a intervenção do Estado no domínio econômico, percepção que conflitava com sua anterior menção à "concepção manchesteriana da economia e das finanças" (Benevides, 1981, pp. 197-198).

O "Manifesto dos Mineiros", principal documento fundador do partido na mitologia udenista, já afirmava, mesmo em tempos de autoritarismo e da ampla predominância de Vargas no aparelho estatal, que a "democracia por nós preconizada não é mesma do tempo do liberalismo burguês" (Franco 1946, p. 109). Para os udenistas mineiros, quase todos bacharéis, "o tempo do liberalismo passivo já findou” (Idem, ibidem), de modo que a época demanda a "democratização da economia" (Idem, ibidem). O "Primeiro Programa" do partido segue a mesma toada, com a defesa da ação estatal para "promover e estimular a industrialização" e a afirmação de que "as indústrias estratégicas ficarão a cargo do Estado" (UDN, 1945). O desenvolvimento e o planejamento, marcas da época, também comparecem, com a previsão de intervençôes diretas e indiretas do Estado na economia "para a elaboração, ouvidas as classes interessadas, dos planos que favoreçam o desenvolvimento dos diversos setores da economia" (Idem).

Nem só nos primeiros anos, todavia, os udenistas se mostraram elogiosos da ação estatal na economia. Vários bacharéis se manifestaram de modo favorável ao uso do planejamento e à ideia de um Estado interventor, em tom bem distinto do liberalismo de Gudin (Simonsen e Gudin, 2010), que via no planejamento estatal o início da implantação do comunismo. Afonso Arinos, por exemplo, declarava diretamente, em artigo no Digesto Econômico, que "nas sociedades modernas o intervencionismo estatal é absolutamente inevitável" (Franco, 1961b, p. 123), uma vez que "o plano econômico-social do Governo deverá tornar-se [...] uma das características inseparáveis da moderna democracia" (Idem, p. 124). As mudanças vivenciadas pelo mundo desde o término da Primeira Guerra Mundial impunham, segundo o bacharel, novas fórmulas e soluçóes políticas que ultrapassavam antigas crenças, como a oposição entre planejamento e democracia, arcaica concepção que vincula a democracia ao liberalismo econômico. O raciocínio equivocado confunde, sem perceber, componentes constitutivos do ideário democrático com resquícios contingentes de formaçôes históricas já superadas:

[...] há certos fundamentos da doutrina democrática que servirão sempre de alicerce à construção da democracia, mas outros existem que correspondem não aos aspectos doutrinários da democracia, ao que ela tem de autêntico, de permanente, de irredutível à marcha da História, mas que correspondem somente às condiçóes econômicas de períodos históricos já transpostos. [...] proponho designar os fundamentos transitórios da democracia clás- 
sica, dependentes de condiçóes econômicas desaparecidas, com o nome de elemento liberal da economia, adotando a fecunda sugestão de Hans Kelsen, segundo a qual a democracia moderna pode não ter nada de liberal no sentido econômico (Idem, ibidem).

A democracia contemporânea não apenas admite, aos olhos do bacharel conservador, uma intervenção estatal mais forte, mas a exige. $\mathrm{O}$ próprio êxito da democracia enquanto forma de governo demandaria o recurso às modernas técnicas de planejamento, sendo esta "a mais séria de todas as questôes governativas do Estado Moderno" (Idem, p. 311). Arinos é, deste modo, peremptório ao afirmar que "a democracia atual não prescinde do planejamento, por menos que o aceitem aqueles que confundem democracia com liberalismo. O planejamento democrático tornou-se mesmo elemento inseparável do êxito da democracia como forma de governo." (Idem, ibidem) Não sem razão, este tem sido o caminho pelas principais democracias do Ocidente, fiéis representante, da "cultura ocidental, no que tem de mais puro e de mais alto" (Idem, p. 124). Nesse sentido, por exemplo, caminha "a ciência e a prática políticas da Grã-Bretanha” (Idem, ibidem), que tem demonstrado a "perfeita compatibilidade entre a técnica da liberdade política, coração da democracia, e um maciço antiliberalismo econômico [...] traço marcante do nosso tempo" (Idem, ibidem). Os liberais econômicos mais empedernidos surgem no discurso do bacharel mineiro como verdadeiras relíquias, pouco ajustadas ao espírito do novo tempo. Até mesmo sua existência deve ser reiterada para os leitores mais incrédulos:

Os economistas liberais - ainda hoje os há e alguns de irrecusável mérito - opóe frequentemente ao planejamento, considerando-o forma de ditadura. Porém, os políticos e os juristas democráticos não participam mais dessa radical opiniáo. Hoje se tem por assentado [...] que, preservadas as regras básicas da liberdade democrática, a política intervencionista do Estado não é incompatível com o regime. E o planejamento é a forma superior e sistemática do intervencionismo (Idem, p. 180). ${ }^{3}$
Distintamente de Gudin, que reiterava as críticas de neoliberais como Hayek, Arinos tecia enormes elogios ao longevo presidente norte-americano Roosevelt - dedicando-lhe, inclusive, um dos seus discursos-homenagens da tribuna parlamentar -, consonante com a admiração que boa parte do partido também demonstrava, tendo inclusive citado Roosevelt no programa da campanha de 1945 como exemplo de que "a liberdade que protege o homem do terror do Estado nada tem a ver, não é causa nem efeito obrigatório, do liberalismo econômico, com o qual chegou a ser confundido"” (Benevides, 1981, p. 199). ${ }^{4}$ Roosevelt surgia, nas palavras de bacharel e no programa de 1945, como símbolo das elites sensíveis às necessidades das classes populares e, justamente por isso, capazes de desempenhar seu papel de estadistas em um tempo de profundas mudanças (Franco, 1965, p. 97).

Com seu liberalismo conservador de fortes tons oitocentistas, inspirado por figuras como Nabuco e Tocqueville, ${ }^{5}$ Arinos demonstrava como o passar dos tempos pode dar feiçóes modernas a ideias que, alguns anos antes, soavam antiquadas. Como exposto de maneira genial no "Pierre Menard, autor de Dom Quixote", de Borges ([1944] 1998), as obras ganhavam novos sentidos com o passar dos tempos e sugeriam significados antes imprevistos. A desconfiança de tons aristocráticos perante o desencantamento do mundo produzido pelo capitalismo, que reduzia tudo ao equivalente comum da mercadoria, soava arcaica em tempos de pujança do livre mercado, mas agora, passada a crise de 1929 e as mazelas de mais uma guerra mundial, demonstrava afinidades com ideias mais contemporâneas, como o keynesianismo e o desenvolvimentismo cepalino que, em meio ao seu mar de diferenças, compartilhavam da mesma crítica à pretensão de plena eficiência do mercado. O planejamento, último grito da modernidade para muitos dos pensadores da época, não soava estranho aos ouvidos de alguém que reclamava integrar a antiga linhagem ibérica brasileira (Vianna, 2004). Saltavam à vista as semelhanças, como o papel de destaque atribuído ao Estado para organizar as demandas sociais e apontar os rumos mais adequados para o mundo social. Claro que o instrumento podia descambar para terrenos perigosos na visão de Arinos, como os devaneios soviéti- 
cos pregados por alguns insensatos avisavam, mas nesse caso o problema era do excesso de liberdade concedido às massas e da baixa qualidade das elites que então ocupavam o poder, não do antigo afã interventor do Estado. Bastava, ao menos em um primeiro momento, o aviso de que "naturalmente o planejamento democrático difere muito do ditatorial" (Franco, 1961b, p. 180).

A defesa de uma especificidade brasileira também aproximava o bacharel dos modernos economistas cepalinos, como Prebisch e Furtado, que apontavam a necessária adaptação de teorias centrais quando da sua recepção em contextos periféricos como o brasileiro. ${ }^{6} \mathrm{O}$ olhar para o local, que marcava o bacharel conservador, o levava a um terreno mais próximo dos desenvolvimentistas e deixava-o distante da companhia de um inflexível Gudin, que postulava a existência de uma única teoria econômica - já que eram universais o mercado e o indivíduo liberal - e pensava ser desnecessária qualquer inflexão para a análise da periferia.

\section{Economia e política segundo Aliomar Baleeiro}

Arinos, por certo, era um dos mais elogiosos desse novo papel do Estado, mas ele não estava de nenhum modo sozinho. Aliomar Baleeiro, bacharel modernizante que em diversos momentos defendeu políticas mais próximas ao campo do liberalismo econômico, não poucas vezes destaca em sua obra a necessidade de um papel ativo do aparato estatal, fato que surge como evidência incontrastável dos novos tempos, marcados pela "intervenção crescente do Estado, em quase todos os ramos da atividade humana" (Baleeiro, 1970, p. 3). O fenômeno atinge até mesmo, as naçóes mais identificadas com o liberalismo econômico e o capitalismo: "Nos países mais individualistas [...] não só se agigantam as despesas públicas, [...] senão também se hipertrofia a competência dos poderes públicos..." (Baleeiro, 1955 , p. 55). Recorrendo à organização cronológica típica dos manuais jurídicos, que costuma começar com as formas mais arcaicas e precárias para, ao fim, atingir os institutos elaborados, Baleeiro opóe o Estado gendarme do liberalismo econômico, cujos pressupostos políticos são claramente expostos ao longo do texto, ${ }^{7}$ às incontornáveis inovações promovidas por Keynes nas ciências econômicas, marcas de um novo tempo:

Os progressos das ciências econômicas, sobretudo depois do impulso que lhes imprimiu a teoria geral de Keynes, refletiram-se na Política Fiscal e esta, por sua vez, revolucionou a concepção da atividade financeira, segundo os preceitos dos financistas clássicos. Ao invés das "finanças neutras da tradição", com seu código de omissão e parcimônia tão ao gosto das opiniôes individualistas, entendem hoje alguns que maiores benefícios a coletividade colhera de "finanças funcionais", isto é, a atividade financeira orientada no sentido de influir sobre a conjuntura econômica. Destarte, o setor público - a "economia pública" náo se encolhe numa vizinhança pacífica e tímida junto às lindes da economia privada. A benefício desta é que deve invadi-la, para modificá-la, como elemento compensador nos desequilíbrios cíclicos (Idem, p. 44).

O campo intelectual reflete e influencia os novos papeis e conceitos de Estado, de modo que "ao Estado gendarme sucede o Estado de serviços públicos e de bem-estar geral, o welfare State" (Idem, p. 170), forma política marcada pelo predomínio do planejamento, quase uma unanimidade à época: "A planificação passou a ter o encanto das palavras mágicas. Sonha-se com uma época em que não se reproduza jamais o paradoxo da miséria na abundância, ou do subconsumo no auge da superprodução" (Baleeiro, 1960, p. 409). Não seria mais possível, por essa concepção, olhar as relações entre o aparato estatal, o direito e a economia do mesmo modo, pois se deviam reconhecer as imposiçóes dos novos tempos.

A identificação de transformaçôes nas esferas econômica e jurídica não importa, entretanto, a negação do seu caráter político. Não sem motivo o jurista inicia seus três livros destinados a servirem de manuais nos cursos de direito - Limitaçôes constitucionais ao poder de tributar, Introduçâo à ciência das finanças e Direito tributário - com advertências sobre 
o caráter inapelavelmente político desses campos. A política dá sentido e direção à complexidade do mundo social, que náo opera mecanicamente, mas pelo constante afluxo da ação humana. $\mathrm{O}$ ato político não se dá, contudo, em meio ao vácuo ou toma a sociedade como massa informe, mas, distintamente, torna-se mais eficiente à medida que percebe os contornos e caminhos mais profícuos do contexto. A insistência no formalismo jurídico e nos princípios imutáveis não são marcas dos estadistas, que se distinguem, justamente, pela capacidade de contornar situaçóes aparentemente adversas e optar pelas melhores soluçôes, mesmo que muitas vezes contrariamente às suas crenças abstratas.

Baleeiro escreveu um livro em defesa da atuação de Rui Barbosa à frente do Ministério da Fazenda do Governo Provisório (Baleeiro, 1952), tendo por argumento central a ideia de que, apesar de seus amplos conhecimentos no campo da economia, usualmente subestimados pela historiografia do período, Rui foi, acima de tudo, alguém que colocou a política em primeiro lugar. As criticadas consequências inflacionárias das suas medidas se justificariam, nesse sentido, como forma de manter a ordem republicana recém-instaurada, que talvez não sobrevivesse em um cenário de contenção de gastos e despesas.

Rui Barbosa [...], ainda que houvesse desdobrado a sua espantosa capacidade de trabalho sobre os diversos problemas específicos da pasta, em verdade a dirigia com profundo sentido político, que serve de medida de coordenação entre as várias medidas características de sua rápida passagem pelo poder. [...] O problema econômico e financeiro, embora o estudasse profundamente à luz doutrinária, equacionou-se, para ele, em termos políticos: qual a solução admissível com o mínimo de inconveniências no momento em que, pela força, o novo regime se implantara, provavelmente sem apoio de toda ou da maior parte da opinião pública. Os dados do problema não poderiam ser fixados em algarismos e representações gráficas, embora - diga-se de passagem - Rui houvesse tomado providências eficientes, desde 1889, para conhecimento tanto quanto possível exa- to da situação financeira e instituísse todo um sistema para extensão - e aperfeiçoamento das estatísticas do tesouro (Idem, pp. 74-76).

O "Rui político" soube colocar os interesses do país acima das suas convicções ${ }^{8}$ e agir como verdadeiro estadista: "A capacidade de transigir de Rui [...] mostra que o estadista contrasta vivamente com a rigidez e a inflexibilidade do combatente na defesa dos direitos e liberdades" (Idem, p. 100). Esse é o modelo de Baleeiro, que vê no direito e na economia instrumentos da ação política, meios, não fins: "Ora, a valorização da justiça ou injustiça na atual distribuição da propriedade não pode ser resolvida cientificamente. É um julgamento ético e político..." (Baleeiro, 1960, p. 409). Nada mais distante do perfil do político udenista que a ideia de um baluarte do "bacharelismo", ignorante das maiores novidades da ciência econômica. As mençóes e reflexóes em torno de Keynes, Hayek e Von Mises ao longo da década de 1950 mostram que ele estava atento ao debate econômico contemporâneo, mesmo que, é claro, não manejasse o mesmo arsenal técnico e estatístico que alguns economistas. Mais do que um desconhecimento do debate, se delineia em Baleeiro o exemplo de uma distinta concepção da economia, francamente politizada e, por isso mesmo, refratária ao naturalismo que cerca os argumentos de certo liberalismo econômico mais ortodoxo (Kervegan, 2004).

A construção dessa concepção política da economia faz-se presente tanto na submissão das suas convicçôes econômicas aos sabores mais voláteis das conjunturas quanto na defesa de um papel mais forte do Estado em determinadas situações. Baleeiro, como bacharel modernizante, tinha uma relação ainda mais afável que Arinos com os mecanismos de mercado: mesmo reivindicando uma tradição liberal brasileira - conhecida pelas artes da composição e da construção institucional por meio da política -, desempenhou um papel extremamente ativo na modernização do direito nacional, buscando afastá-lo do verbalismo juridicista e torná-lo apto a atuar perante o moderno mundo da economia. Náo à toa, o bacharel foi autor de uma proposta de reforma do ensino jurídico, apresentada na Câmara dos Deputados (Venâncio Filho, 2004, pp. 313- 
314), e um dos pioneiros na introdução de disciplinas como direito tributário e direito financeiro ainda nos quadros de cursos de ciências jurídicas, fortemente marcados pelo beletrismo coimbrão tardio e pela ampla predominância do direito privado em detrimento do direito público. ${ }^{9} \mathrm{O}$ recurso ao direito público francês ${ }^{10}$, amplamente hegemônico no Brasil até a Revolução de 1930, convivia com um contato cada vez maior com um direito público norte-americano extremamente preocupado com as novas formas econômicas delineadas no horizonte. Nesse sentido, seu liberalismo náo possuía o mesmo tom oitocentista que de o Arinos, mesmo que este também tenha refletido sobre as novas relaçóes entre o direito e a economia (Franco, 1961b).

A defesa eventual de açóes mais fortes do Estado não se mostra, desse modo, dissonante das suas concepçóes teóricas ou mesmo do seu discurso como homem público. Se o mercado, para Baleeiro, era um mecanismo eficiente de alocação de recursos sociais, em nenhum momento o bacharel baiano submeteu o Estado e a razão política aos seus desígnios, mas, distintamente, sempre se mostrou disposto a limitar, por meio da ação política, os eventuais excessos da lógica mercantil. A reflexão vale para o debate em torno da Campanha do Petróleo, mas também para outros momentos, como a crítica, feita em plena década de 1950 , ao caráter regressista do sistema tributário brasileiro (Baleeiro, 1960, cap. 18), seguida pelo reconhecimento de que as contribuições dos tributos à redução da desigualdade se mostravam necessárias em um mundo marcado pelos aumento da demanda por igualdade, herança das experiências socialistas. ${ }^{11} \mathrm{O}$ feroz anticomunismo de Baleeiro convivia com um esforço de realismo político.

\section{A perspectiva de Bilac Pinto}

Bilac Pinto, autor da emenda que estabeleceu o monopólio estatal do petróleo, seguia caminhos bem semelhantes aos de Baleeiro, irmanado em um mesmo liberalismo modernizante. Aproximava-os uma concepção quase idêntica do papel do direito, da economia e das suas relaçóes com a política, a qual convivia ao lado, nos dois casos, com uma ver- ve retórica de grande agressividade e forte tom anticomunista, responsável por levar os dois bacharéis a postos de destaque na "banda de música"12 udenista. O bacharel mineiro também desempenhou papel relevante na modernização do debate jurídico nacional, seja nas cátedras que ocupou ou, já mais velho, à frente da editora Forense.

Os temas dos seus artigos publicados ao longo das décadas de 1940 e 1950 coincidem com as preocupaçóes e com muitas das respostas de Baleeiro, o que sem dúvida revela um sinal de convivência nos mesmo ciclos político-intelectuais e aponta para o clima da época. O reconhecimento de uma significativa ampliação das áreas de atuação do Estado figura, por exemplo, já nas primeiras páginas dos seus Estudos de direito público, em que Bilac destaca como marca do tempo a emergência de "múltiplas formas de intervenção do Estado no domínio econômico e social" (Bilac Pinto, 1953a, p. 2). Trata-se, afinal, de uma característica imanente ao próprio Estado Moderno, que tende a ampliar sua ação em prol do bem geral: "A principal característica do Estado Moderno, em todos os meridianos políticos do mundo civilizado, é a incoercível tendência para ampliar e diversificar a sua" (Idem).

Os exemplos levantados no campo da política comparada - nas grandes pátrias do liberalismo econômico e do capitalismo, a Inglaterra e os Estados Unidos - reforçam o argumento e buscam demonstrar, inequivocamente, como as radicais transformaçóes institucionais e intelectuais impostas pela ampliação do Estado ganharam o caráter de fato quase incontestável. O trecho a seguir, acerca das consequências dessas mutaçôes para as práticas do governo, demonstra bem a forma como, na visão de Bilac Pinto, todos os meandros das instituiçóes democráticas passaram por profundas modificaçóes motivadas pela nova realidade:

A Inglaterra e os Estados Unidos, com efeito, tendo sofrido com intensidade sem igual o impacto da industrialização e da concentração econômica, tiveram que atender às profundas e variadas repercussóes dessas causas primárias no plano de governo. Dentre essas repercussóes cumpre assinalar a intervençáo do Estado na ordem econômica e no domínio social, que 
passou a constituir um dos mais indeclináveis e imperativos deveres do Estado. [...] A estrutura orgânica e funcional do Estado, modelada no pressuposto do quadro econômico e social do laissez-faire, teria, necessariamente, que se manifestar inadequada para atender aos novos tipos de atuação que dele se reclamava. As funçôes do Estado, além de terem se ampliado sensivelmente, assumiram aspectos novos. A legislação cresceu em volume e em complexidade pois teve que descer até os detalhes das mais diferentes técnicas (Idem, pp. 250-251).

Como derivação dessa nova feição estatal, ocorre uma grande ampliação do campo do direito administrativo, de onde surge, naturalmente, a "importância que esse ramo do direito vem assumindo, contemporaneamente, nos regimes democráticos" (Idem, p. 2). As referências intelectuais são muito semelhantes às de Baleeiro, com a forte presença do direito público francês convivendo com o crescente interesse pelas novas perspectivas do direito norte-americano. ${ }^{13}$ Bilac revela, entretanto, um aspecto interessante dessa influência, ao ressaltar o caráter não escrito do direito administrativo francês (Idem, p. 8), o que aumenta as possibilidades de ação dos juristas, e ao destacar o papel do Conselho de Estado, um órgão eminentemente político, na sua construção. A tradição francesa teria, desse modo, uma grande afinidade com a concepção politizada de direito encampada por Bilac e Baleeiro.

Ainda no campo do direito administrativo e das respostas institucionais à nova configuração do Estado, Bilac escreveu seu mais influente texto jurídico - "O declínio das sociedades de economia mista e o advento das modernas empresas públicas" - no qual o bacharel mineiro pensa não apenas como acadêmico no campo do direito, mas justifica, a partir dessa reflexão, sua conduta no caso do monopólio estatal do petróleo. ${ }^{14} \mathrm{O}$ texto se inicia com outra constatação sobre a nova natureza do Estado, agora apresentada como "fato histórico universal". O decantado aumento das dimensões estatais não é retratado, entretanto, em plano formulado e pré-estabelecido, apontando-se ao contrário que "teve caráter fragmentário e se foi operando por consideraçóes de oportunidade prática, no curso das vicissitudes de uma longa história" (Bilac Pinto, 1953b, p. 2). A nova realidade decorre, segundo o autor, antes da necessidade de responder às transformaçóes do mundo do que da vitória prática de uma "imposição doutrinária". Os bacharéis revelam, mais uma vez, seu caráter plástico, mais preocupados com as respostas adequadas às contingências políticas - fundamentais para a realização dos valores maiores aos quais eles se vinculam - do que presos aos esquemas lógico-formais típicos dos juristas. ${ }^{15}$

As modificaçóes dos institutos jurídicos devem, do mesmo modo, responder aos novos tempos, marcados pelas "atividades de natureza industrial ou comercial" que passaram para a competência do Estado. O direito desempenharia, assim, papel fundamental na urgente modernização do Estado brasileiro. Nesse cenário, após uma exposição dos modos de interaçáo entre o poder público e o capital privado, marcada pela crítica subsequente aos modelos da concessão e da sociedade de economia mista, Bilac conclui pela superioridade da moderna empresa pública. Distintamente da concessão, antigo instrumento ainda preso a velhos dogmas liberais, e da sociedade de economia mista, que acabava limitada pelos constantes confrontos entre os interesses públicos e privados, a empresa pública conseguia conciliar a eficiência da empresa privada com a manutenção dos valores públicos mais relevantes. Trata-se, em poucas palavras, de uma empresa que se organiza à moda das corporaçóes privadas, seja em relação à cultura gerencial ou aos direitos trabalhistas, mas que tem por acionista único o Estado. Aliomar Baleeiro, em mais uma semelhança, também elogia tal solução institucional: "As empresas públicas modernas, em consequência, diferem muito das antigas [...] são instrumentos de intervenção governamental para realização daqueles novos fins" (Baleeiro, 1955, p. 170).

O novo Estado interventor precisava, segundo os bacharéis, de eficientes instrumentos para cumprir suas difíceis funçôes, tarefa à qual se prestava perfeitamente o novo modelo de empresa pública. O pioneirismo no esforço de implantação desse instituto no Brasil - não obstante algumas semelhanças com instituições já existentes, como as Caixas Econômicas - surgiu na proposta do próprio 
deputado Bilac Pinto para a criação da Empresa Nacional do Petróleo (Enape), que regularia, no substitutivo udenista que instituía o monopólio, a exploração estatal do petróleo.

A proposta udenista, segundo a pena de Bilac, não flertava com valores do campo adversário, getulista, que se caracterizava pela hipertrofia de caráter quase autoritário do aparato estatal, mas pretendia implantar modernos padróes de gestão pública "um progresso significativo na arte da administração pública" (Idem, p. 15) -, adequando o arcaico Estado brasileiro aos valores e práticas mais avançados do mundo público. Se o Estado não podia ser mais tomado como necessariamente inepto, como alguns argumentavam em outros tempos, a mesma afirmação não se aplicaria ao aparato estatal brasileiro, ainda assolado, aos olhos udenistas, pela série de vícios descritos em tom nada ameno nas tribunas parlamentares e nas páginas da grande imprensa.

A argumentação algo extensa em torno do flerte do bacharéis com um Estado ativo - o que não dá qualquer feição de anomalia ao caso do monopólio do petróleo - não implica, todavia, a ideia de um radical estatismo por parte dos udenistas ou em qualquer recusa radical ao mundo mercantil. Seria possível também elencar alguns discursos virulentos dos udenistas em sentido diverso, a defender que os limites impostos pelos governos adversários ao capital estrangeiro tinham tintas autoritárias, usualmente de tons vermelhos. Aliás, as disputas em torno do capital estrangeiro colocavam-se entre os mais duros embates a envolverem udenistas na arena pública, como demonstra a constante divisão do partido em torno do tema, um dos que mais o fracionavam. ${ }^{16}$

A forte campanha contra a Lei Malaia, ${ }^{17}$ a franca defesa da polêmica Instrução 113 da Sumoc, promulgada por Gudin, ${ }^{18}$ a violenta reação à Lei de Remessa de Lucros, ${ }^{19}$ de Goulart - não são poucos os momentos em que a defesa do capital estrangeiro, visto pelos udenistas como fundamental para a o desenvolvimento do país, emergiu como plataforma central do partido. Se, por um lado, a UDN se dividia em relação ao tema - com o campo nacionalista representado por personagens emblemáticos como Gabriel Passos -, era mais comum, por outro lado, ver parlamentares udenistas à frente da argumentação antinacionalista. Muito corriqueiras eram, por exemplo, as críticas ao protecionismo que, segundo os udenistas, beneficiava injustamente certos segmentos da indústria nacional. ${ }^{20} \mathrm{O}$ próprio programa do partido de 1945 não se furta a fazer menção expressa à importância dos recursos estrangeiros, inclusive com a sempre lembrada defesa do "aproveitamento de nossas reservas inexploradas": "Apelar para o capital estrangeiro, necessário para os empreendimentos da reconstrução nacional e, sobretudo, para aproveitamento das nossas reservas inexploradas" (UDN, 1945). Como bem destaca Maria Victoria Benevides, a defesa de um tratamento igualitário entre capital nacional e estrangeiro seria uma marca constante do partido (Benevides, 1981, p. 198), mesmo que, em contrapartida, a posição sempre tenha enfrentado fortes resistências internas.

As flutuações de posição respondem, naturalmente, aos sabores da dinâmica política, que impóem o sacrifício de convicçóes, mas não se restringem a isso. É claro que o papel de eterna oposição enquanto que, na feliz expressão de Maria Victoria Benevides, "o Estado era Getúlio Vargas” (Idem, p. 197) - condiciona certas posiçóes antiestatistas, do mesmo modo que o interesse em vitórias pontuais pode levar a adesóes a ideologias estranhas ao mundo liberal. Não penso ser possível afirmar que as variaçóes impliquem, todavia, uma ausência de "modelo econômico", mas antes a construção de um modelo que não se identifica, mesmo que eventualmente possa concordar, com o liberalismo econômico mais ortodoxo do período.

\section{Consideraçóes finais: os bacharéis e a República de 1946}

Olhando para o pensamento econômico brasileiro da época, organizado por Bielschowsky (2004) entre uma ortodoxia liberal, uma corrente socialista e três variantes do desenvolvimentismo separados tanto pelo papel do Estado quanto pela origem de atuação dos seus intelectuais - os bacharéis udenistas mostram-se mais próximos, mesmo que com diversas ressalvas, de uma das variantes do desenvolvimentismo, a do setor público não nacionalista, do que da corrente intitulada pelo autor de 
"pensamento neoliberal". Aproxima-os, sobretudo, a perspectiva sobre o papel do Estado na economia. O conceito que dá nome a essa corrente - a qual tem como principal representante Roberto Campos, mas também enquadra nomes importantes, como Lucas Lopes e Glycon de Paiva - precisa, entretanto, ser antes debatido.

Bielschowsky cunha o termo inspirado em conceito de desenvolvimentismo quase exclusivamente econômico que, como ele várias vezes ressalta, "é definido como a ideologia de superação do subdesenvolvimento através de uma industrialização capitalista, planejada e apoiada pelo Estado" (Idem, p. 431). O contraponto constante é a proposta neoliberal, com o socialismo frequentemente tomado como posição menor no campo das ideias econômicas do período, por sua menos articulada reflexão sobre os temas da economia. ${ }^{21}$ A grande questão do livro é, nesse sentido, compreender as razóes pelas quais um campo desenvolvimentista que se mostrava táo amplo nos anos de 1950 e 1960 de modo que é possível falar em um "ciclo ideológico do desenvolvimentismo" - acabou reduzido nas décadas seguintes. O desafio, para tanto, não é explicar a posição de desenvolvimentistas genuínos, como os nacionalistas Celso Furtado e Rômulo Almeida, mas compreender por que futuros liberais, entâo congregados nos grupos que Bielschowsky intitulará "desenvolvimentistas não nacionalistas" e "desenvolvimentistas do setor privado", abraçavam com entusiasmo algumas teses desenvolvimentistas.

Pensando na época, entretanto, e com o olhar voltado sobretudo para o discurso econômico, fazia mais sentido chamar figuras como Roberto Campos de desenvolvimentistas, mesmo que de uma vertente mais moderada - a "ala direita da posição desenvolvimentista” (Idem, p. 105) -, que os taxar de liberais. A criteriosa análise empreendida por Bielschowsky sobre Campos, que em alguns anos se tornaria um dos mais célebre representantes do liberalismo econômico brasileiro, justifica a opção. Nesse momento, a aliança com os "desenvolvimentistas nacionalistas" se mostrava natural, pois "pouco havia nos discursos de Campos de 1952 que não pudesse merecer o aplauso dos nacionalistas" (Idem, p. 344). Já "na segunda metade dos anos 1950, quando [...] a industrialização com apoio estatal já aparecia como um fato consumado", o cenário do debate econômico passa a privilegiar outros aspectos, que progressivamente afastam Campos da companhia dos nacionalistas e o aproximam da ortodoxia liberal. ${ }^{22} \mathrm{~A}$ distância firma-se a partir da recessão do início dos anos de 1960, responsável pelo fortalecimento do debate sobre questóes redistributivas até então relegadas ao segundo plano pelos desenvolvimentistas, que se mostravam confiantes nas benesses da industrialização como remédio para todos os males. Com a industrialização consolidada e a decadência do crescimento via substituição de importaçóes, passava ao primeiro plano não a questão do crescimento, mas a maneira como seriam divididos os recursos em tempos de escassez. Temas como a estabilização monetária e o lugar do capital estrangeiro, que já antes dividiam o campo desenvolvimentista de Bielschowsky, ganham grande importância e reconfiguram a organização do debate econômico. Nesses novos tempos, sob a perspectiva do debate adotada pelo autor, já seria possível ver Campos como liberal, o que ganha força com as transformações do seu próprio pensamento no pós-1964.

Para a ótica do presente trabalho, que vê o liberalismo não apenas como uma doutrina econômica, mas também como uma visão de mundo ${ }^{23}$, o Campos dos anos de 1940 e da primeira metade dos anos de 1950 é, mesmo antes das transformaçôes na conjuntura e em seu pensamento, um liberal, assim como outros protagonistas do desenvolvimentismo "não nacionalista". Se no campo da economia o elogio ao planejamento e à intervenção estatal, mesmo que suplementar ao Estado, já afasta alguns dos autores do campo liberal, efeito semelhante não ocorre no debate da história e da teoria política. O problemático uso de definiçóes pela negação - tal como no termo "não nacionalista", cunhado por Bielschowsky -, quase sempre imprecisas, pode ser, nesse caso, substituído com ganho pela identificação de outro tipo de liberalismo, menos otimista em relação à plena eficiência do mercado, mas, ainda assim, identificado com diversos pressupostos da visão liberal do mundo.

Mesmo que por razóes distintas do presente trabalho, pois amparadas em obscura distinção entre os nacionalismos "de fins" e "de meios", o próprio Campos faz boa ressalva ao conceito, pro- 
pondo uma opção mais interessante sob o ponto de vista dessa pesquisa: "liberal-desenvolvimentistas". ${ }^{24} \mathrm{O}$ ponto, bem exposto pelo novo conceito, é demonstrar como a força da vaga desenvolvimentista foi capaz de mobilizar mesmo liberais mais moderados, que não viam na conjuntura de então alternativas a uma intensa atuação do Estado, mesmo que - é bom ressaltar - conjugada à forte participação da iniciativa privada, inclusive do capital estrangeiro. A presente perspectiva faz desse primeiro Roberto Campos, como já foi dito, o economista que mais se aproximava da perspectiva dos bacharéis udenistas.

Ele se mostrava, à época, distante de uma ortodoxia de corte manchesteriana (Idem), já que admitia a necessidade da intervenção estatal para superar os severos obstáculos enfrentados pelo desenvolvimento brasileiro. O planejamento, palavra da moda, era instrumento fundamental para a tarefa, sobretudo para superar aquilo que Campos chamava de "pontos de estrangulamento", setores fundamentais da economia que, por seu escasso desenvolvimento técnico, falta de investimento ou de capital humano adequado, impediam o desenvolvimento de todas as demais áreas. O Estado deveria se preocupar, sobretudo, com esses setores críticos, os quais teriam seus problemas identificados e solucionados pelo esforço de planejamento. ${ }^{25}$

O plano econômico, para Campos, não apenas se mostra muito menos ambicioso que a ideia cepalina de um planejamento integral da economia, que o economista tratava como impraticável, mas também emergia, à moda de Roberto Simonsen, como simples instrumento técnico, desprovido de maior semântica política ou ideológica. ${ }^{26} \mathrm{~A}$ importância do Estado náo deveria em nenhum momento usurpar a ação fundamental da iniciativa privada, pouco importando se nacional ou estrangeira, já que, aos olhos de Campos, a origem do capital era problema secundário.

Os bacharéis udenistas, especialmente os modernizantes, adotaram postura bem próxima a Campos ao longo da década de 1950. As opiniôes são especialmente parecidas nas duas questôes mais relevantes do debate econômico da época: o papel do Estado na economia e o tratamento do capital estrangeiro. A influência do discurso desenvolvi- mentista e das críticas acumuladas, já há algumas décadas, sobre o laissez-faire, os levava a ressaltar a necessária atuação do Estado no mundo político e econômico, diretamente vinculados a uma tradição nacional que sempre buscou conciliar princípios liberais ao protagonismo do Estado. ${ }^{27}$ Se esses bacharéis recusavam no mais das vezes um liberalismo econômico ortodoxo, por outro lado não negavam em nenhum momento o papel fundamental da iniciativa privada em seu arranjo político-econômico. Além disso, recusavam quase sempre as defesas mais arraigadas do nacionalismo. A UDN, como mencionado, sempre ressaltou em seus programas a indistinção entre o capital nacional e o estrangeiro, ${ }^{28}$ assim como se mostrou frequentemente crítica do protecionismo. Pensando no quadro ideológico desenhado por Bielschowsky, nada mais coerente do que enquadrá-los no grupo dos "desenvolvimentistas não nacionalistas" ou, como propus, "liberal-desenvolvimentistas".

As diferenças são tão ou mais eloquentes que as semelhanças. Distintamente da visão politizada da economia dos bacharéis, Campos construía um discurso de fortes tons tecnocráticos, no qual a linguagem da economia predominava e a política com frequência desempenhava o papel de ruído, a desestabilizar, com sua retórica ideológica, os precisos arrazoados econômicos. Enquanto os bacharéis udenistas representam o claro esforço de modernizar longevas linhagens brasileiras, acomodando-as às imposições dos novos tempos, Campos emerge como a imagem do moderno economista - que tanto prestígio teria nas décadas seguintes. Nesse sentido, a guinada que logo se iniciaria em seu pensamento, com a rejeição das suas influências keynesianas em prol de uma maior aproximação com Hayek, é perfeitamente condizente com sua construção como ator político, muito mais confortável em um ideário que subjuga o político ao econômico. Em meio a diferenças tão significativas, o leitor pode questionar as razões da comparação. Os motivos, que são muitos, aparecem a seguir.

A proximidade entre Roberto Campos e os bacharéis expóe o lugar do liberalismo no debate de época e revela as dificuldades que o conceito de mercado então encontrava, quando mesmo partidários das afinidades entre o liberalismo político e o libera- 
lismo econômico - ponto que Campos já então defendia - faziam ressalvas à sua onipotência. $\mathrm{O}$ cotejo também demonstra como a posição mais ortodoxa de Gudin e Bulhóes não era a única vertente liberal disponível no debate econômico da época, convivendo com versões liberais mais flexíveis, que nutriam outras perspectivas sobre o lugar do Estado.

Se o período registra grande aumento da densidade do debate econômico, os bacharéis demonstram que, mesmo falando de uma posição que, no fundo, relativiza sua própria autonomia, não adotam argumentos e perspectivas arcaicas, mas dialogam, mesmo que com distintos pressupostos, em consonância com alguns dos grandes intelectuais do cenário econômico. O liberalismo udenista, nesse sentido, não assumia feiçôes anacrônicas, inserindo-se antes no centro do debate da época. O exercício, por fim, destaca um evento curioso: o partido que melhor caracterizava a oposição ao longo da República de 1946, estando à frente do poder apenas por curtos intervalos, ${ }^{29}$ se mostrou afinado no campo intelectual com o economista que esteve mais próximo da política econômica efetivamente realizada no período. ${ }^{30}$

\section{Notas}

1 O tema do bacharelismo é mote central do pensamento político social brasileiro, sendo desenvolvido por autores de destacada relevância e grande variedade, como Oliveira Viana, Sergio Buarque de Holanda, Raymundo Faoro, entre outros.

2 Posição semelhante é exposta por Wanderley Guilherme dos Santos, em seu conhecido texto sobre o liberalismo brasileiro: "os liberais doutrinários, no Brasil, apegavam-se a um programa econômico já bastante ultrapassado" (Santos, 1998, p. 40).

3 Arinos repete o assunto em suas memórias: "Contraditando alguns inamovíveis liberais [...] sustentei, com apoio de vários atores modernos, a perfeita compatibilidade entre o planejamento econômico e a moderna democracia” (Franco, 1965, p. 251).

4 Roosevelt era, curiosamente, muitas vezes também elogiado por Vargas, como aponta Neto (2013).

5 Um bom exemplo do elogio de Arinos aos dois pensadores está em "O humanismo de Nabuco" (Franco, 1961b).
6 Em relação ao pensamento de Celso Furtado, essa questão é bem destacada por Ricupero (2005).

7 "O melhor governo seria o que governasse menos, a melhor despesa a menor possível [...]. Essa concepção tradicional é designada como a das finanças neutras. Não é menos política por isso" (Baleeiro, 1955, pp. 37-38).

8 "Rui, de porta-estandarte do federalismo na luta áspera contra a coroa vacilante sobre a cabeça do velho monarca, passa [...] ao papel de defensor da União contra a exageração de franquias pretendidas pelos Estados" (Baleeiro, 1952, p. 77).

9 Baleeiro comenta isso na introdução ao seu Direito tributário (Baleeiro, 1970).

10 Sobre a relação entre os bacharéis udenistas e o direito público francês se mostra especialmente exemplificativo o comentário de Arinos sobre Odilon Braga (Franco, 1961b, pp. 388-389)

11 “[...] parece óbvio que a difusão mais larga e equitativa dos bens e das rendas constituirá o processo seguro de o regime capitalista dissolver as aspiraçóes e ressentimentos em fermentação contra a sua existência” (Baleeiro, 1960, p. 417).

12 A parte da bancada parlamentar udenista mais conhecida por sua retórica inflamada e assiduidade na tribuna passou a ser conhecida como "banda de música", da qual faziam parte bacharéis como Aliomar Baleeiro, Afonso Arinos e Bilac Pinto.

13 "Até hoje os juristas brasileiros, salvo raras exceçôes, tem seguido [...] o direito francês [...] a influência francesa já não é exclusiva, embora tenha sido predominante, podendo-se identificar [...] o direito norte-americano" (Bilac Pinto, 1953a, p. 7).

14 O texto é fruto de uma conferência de 1952 na Fundação Getúlio Vargas.

15 A distinção entre bacharéis e juristas, desenvolvida por Franco (1965), é analisada em Chaloub (2015).

16 Wanderley Guilherme aponta: "Para o PSD e a UDN, a questáo do capital estrangeiro teve efeito explosivo, caindo ambos para os seus mais baixos índices de unidade partidária, a UDN, na realidade, quase partindo-se ao meio" (Santos, 2003, p. 204).

17 A Lei Malaia - apelido dado pelas feiçóes do seu autor, Agamenon Magalhães, à lei antitruste promulgada em 1944 - previa fortes restriçóes ao capital estrangeiro e foi fortemente combatida pelos udenistas, sendo, afinal, revogada menos de um ano depois do início da sua vigência, em 1945 .

18 A Instrução 113 permitiu a importação de equipamentos por empresas estrangeiras sem cobertura cam- 
bial. Foi motivo de grande disputa política e amplo debate econômico. Sobre o debate, ver Bielschowsky (2004) e Draibe (1985).

19 A lei de 1962 é mais um capítulo do longo debate em torno da remessa de lucros, já problematizada por Vargas em sua famosa mensagem presidencial de 1951. Toda a questão, como no caso da Instrução 113, passava pelo tratamento a ser dispendido ao capital estrangeiro.

20 "Considerações de ordem econômica, certas ou errôneas, sinceras ou maliciosas, sempre serviram de pretexto a iniquidades fiscais. As tarifas aduaneiras protecionistas são o exemplo mais flagrante e universal destas práticas" (Baleeiro, 1960, p. 382).

21 Há, segundo o autor, uma aparente contradição do PCB que ao mesmo tempo que se filiava a uma visão de mundo de forte tom economicista refletia escassamente sobre o "modo de produção brasileiro". A questão encontra uma ótima análise em Brandão (1997).

22 Campos - que tece enfáticos elogios à interpretação de Bielschowsky, o que, por certo não a torna necessariamente válida - dedica boas páginas de suas memórias a esse caminho rumo ao liberalismo.

23 O liberalismo não é aqui apenas definido como sistema econômico, mas também visto como um determinado olhar para o mundo, que ultrapassa os limites da economia. Nesse sentido, o enquadramento de Campos como um liberal não passaria apenas por seu lugar no debate do campo.

24 "A análise de Bielschowsky é substancialmente acurada, conquanto se possa acusar de inadequada a expressão 'desenvolvimentismo não nacionalista'. [...] 'liberal-desenvolvimentistas' teria sido talvez a verbiagem mais acurada" (Campos, 1994, p. 168).

25 A teoria tem grande semelhanças, como bem ressaltam o próprio Campos e Bielschowsky, com a desenvolvida por Hirschman (1960).

26 Em suas triunfalistas memórias, ele afirma: "Bem interpretado - dizia eu - o planejamento é um instrumento neutro, que pode tanto inviabilizar a economia de mercado (pelo planejamento socialista) como auxilia-la" (Campos, 1994).

27 Vianna (2004) e Carvalho (2000) apontam que algumas interpretações do Brasil identificadas ao protagonismo do Estado, como as de Visconde do Uruguai e Oliveira Viana, não recusavam os princípios liberais, mas procuravam, em muitos momentos, conciliá-los a um protagonismo estatal.

28 Apesar da divisão nas votaçôes, fato também já ressaltado a partir de Maria Victoria Benevides (1981).
29 A UDN se afirmou como partido hegemônico no Poder Executivo federal apenas durante os curtos governos Café Filho e Jânio Quadros. Mesmo assim, deve-se ressaltar, nenhum dos dois ocupantes do Poder Executivo era um udenista "puro sangue".

30 "Campos destaca-se nos anos 1950 como um pensador certeiro. Foi [...] o economista da nova ordem [...] foi aquele cujo projeto desenvolvimentista esteve mais próximo da política de investimentos efetivamente realizada” (Bielschowsky, 2004, p. 105).

\section{BIBLIOGRAFIA}

ADORNO, Sergio. (1988), Os aprendizes do poder: o bacharelismo liberal na politica brasileira. Rio de Janeiro, Paz e Terra.

ALMEIDA, Rômulo. (1988), Depoimento ao CPDOC. Rio de Janeiro, CPDOC.

BALEEIRO, Aliomar. (1950), Alguns andaimes da Constituiçâo. Rio de Janeiro, A. M. de Oliveira. (1951), "Carta a Eugênio Gudin: 08/5/1951", in Arquivo Aliomar Baleeiro, Rio de Janeiro, CPDOC-FGV.

. (1952a), Rui, um estadista no ministério da fazenda. Rio de Janeiro, Casa de Rui Barbosa.

. (1952b), "Discurso 18 jun. 1952", in Diário da Câmara, Brasília, Câmara dos Deputados. (1952c), "Diário 11/10/1952", in Arquivo Aliomar Baleeiro, Rio de Janeiro, CPDOC-FGV.

. (1955), Introdução à ciência das finanças. Rio de Janeiro, Forense.

. (1960), Limitaçóes constitucionais ao poder de tributar. Rio de Janeiro, Forense.

. (1961), "Carta a Eugênio Gudin: 16/1/1961", in Arquivo Aliomar Baleeiro, Rio de Janeiro, CPDOC-FGV.

. (1970), Direito tributário brasileiro. Rio de Janeiro, Forense.

BENEVIDES, Maria Victoria de Mesquita. (1976), O governo Kubitschek: desenvolvimento econômico e estabilidade politica: 1956-1961. Rio de Janeiro, Paz e Terra.

. (1981), A UDN e o udenismo: ambiguidades do liberalismo brasileiro. Rio de Janeiro, Paz e Terra. 
BIELSCHOWSKY, Ricardo. (2004), Pensamento econômico brasileiro: o ciclo ideológico do desenvolvimentismo. Rio de Janeiro, Contraponto.

BILAC PINTO, Olavo. (1952), "Discurso Congresso Nacional 6 jun. 1952”. Diário do Congresso Nacional, Brasília, Congresso Nacional.

. (1953a), "O declínio das sociedades de economia mista e o advento das modernas empresas públicas". Revista de Direito Administrativo, 32: $1-15$.

(1953b), Estudos de direito público. Rio de Janeiro, Forense.

. (1963), "Discurso de posse na presidência da UDN", in Arquivo Carlos Lacerda, Brasília, Universidade de Brasília.

(1964), Guerra revolucionária. Rio de Janeiro, Forense.

BORGES, Jorge Luís. (1998), Obras completas. São Paulo, Globo.

BRANDÃO, Gildo Marçal. (1997), A esquerda positiva: as duas almas do Partido Comunista 1920/1964. São Paulo, Hucitec.

CAMPOS, Milton. (1951), Compromisso democrático. Belo Horizonte, Secretaria da Educação do Estado de Minas Gerais.

(1972), Testemunhos e ensinamentos. Rio de Janeiro, José Olympio.

CAMPOS, Roberto. (1994), A lanterna na popa: memórias. Rio de Janeiro, Topbooks.

CANDIDO, Antonio. (2012). Formação da literatura brasileira: momentos decisivos. São Paulo, Companhia das Letras.

CARDOSO, Fernando Henrique. (1973), "Aspectos políticos do planejamento", in B. M. Lafer, Planejamento no Brasil, São Paulo, Perspectiva.

CARVALHO, José Murilo de. (1998), "A utopia de Oliveira Viana", in __, Pontos e Bordados: escritos de história e política, Belo Horizonte, Editora UFMG.

CHALOUB, Jorge Gomes de Souza. (2015), O liberalismo entre o espírito e a espada: a UDN e a República de 1946. Tese de doutorado. Rio de Janeiro, Iesp-Ufrj.

COELHO, Edmundo Campos. (1999), As profissóes imperiais: medicina, engenharia e advocacia no Rio de Janeiro, 1822-1930. Rio de Janeiro, Record.
CONGRESSO NACIONAL. (1952), Diário do Congresso Nacional: 6 jun. 1952. Brasília, Congresso Nacional.

DIGUIT, Leon, (1913), Les transformations $d u$ droit public. Paris, Armand Colin.

DRAIBE, Sônia. (1985), Rumos e metamorfoses: um estudo sobre a constituição do Estado e as alternativas da industrialização no Brasil, 1930-1960. São Paulo, Paz e Terra.

DULCI, Otávio Soares. (1986), A UDN e o anti-populismo no Brasil. Belo Horizonte, Editora UFMG/ Proed.

FONSECA, Pedro Cezar Dutra. (1989), Vargas: 0 capitalismo em construção: 1906-1954. Rio de Janeiro, Brasiliense.

FRANCO, Afonso Arinos de Melo. (1953), "Discurso 16 jan. 1953”. Diário da Câmara, Brasília, Câmara dos Deputados. (1954), "Discurso 9 ago. 1954". Diário da Câmara, Brasília, Câmara dos Deputados.

(1961a), A alma do tempo. Rio de Janeiro, José Olympio (Memórias, n. 1).

. (1961b), Estudos e discursos. São Paulo, Comercial.

. (1965), A escalada. Rio de Janeiro, José Olympio (Memórias, n. 2).

- (1968), Planalto. Rio de Janeiro, José Olympio (Memórias, n. 3).

. (2005), A evolução da crise brasileira. Rio de Janeiro, Topbooks.

FRANCO, Afonso Arinos de Melo \& PILLA, Raul. (1958), Presidencialismo ou parlamentarismo? Rio de Janeiro, José Olympio.

FRANCO, Virgílio de Mello. (1946), A campanha da UDN. Rio de Janeiro, Zélio Valverde.

GUDIN, Eugênio. (1961), "Carta a Aliomar Baleeiro 16/1/1961”. Arquivo Aliomar Baleeiro. Rio de Janeiro, CPDOC-FGV.

GUIMARÃES, Cesar. (2001), "Vargas e Kubitschek: a longa distância entre a Petrobrás e Brasília”, in M. A. R. CARVALHO (org.), República no Catete. Rio de Janeiro, Museu da República.

HAURIOU, Maurice. (1986), Aux sources du droit: le pouvoir, l'ordre et la liberté. Paris, Centre de Philosophie Politique et Juridique.

HIRSCHMAN, Albert. (1960), Estratégia do de- 
senvolvimento econômico. São Paulo, Editora Fundo de Cultura.

KERVEGAN, Jean-François. (2004) "Hayek et le concept d'ordre spontane: les premisses philosophiques, une utopie liberale", in J.-F. Kervégan e H. Mohnhaupt (orgs.), Wirtschaft und Wirtschaftstheorien in Rechtsgeschichte und Philosophie, Frankfurt, Klostermann.

LATTMAN-WELTMAN, Fernando. (2005), $A$ politica domesticada: Afonso Arinos e o colapso da democracia em 1964. Rio de Janeiro, FGV Editora.

NETO, Lira. (2013), Getúlio (1930-1945): do governo provisório à ditadura do Estado Novo. São Paulo, Companhia das Letras.

ROSANVALLON, Pierre. (2002), O liberalismo econômico: história da ideia de mercado. Bauru (SP), Edusc.

SOLA, Lourdes. (1998), Ideias econômicas, decisóes políticas. São Paulo, Editora Unesp.

TOCQUEVILLE, Alexis. (2001), Democracia na América. São Paulo, Martins Fontes.

UDN - Uniāo Democrática Nacional (1945), "Programa Partidário de 17 de agosto de 1945”, in Arquivo UDN, Rio de Janeiro, Instituto Histórico e Geográfico Brasileiro. . (1957), "Programa Partidário de 1957", in Arquivo UDN, Rio de Janeiro, Instituto Histórico e Geográfico Brasileiro.

VENANCIO FILHO, Alberto. (2004), Das arcadas ao bacharelismo: 150 anos de ensino jurídico no Brasil. São Paulo, Perspectiva.

VIANNA, Luiz Werneck. (1999), Liberalismo e sindicato no Brasil. Belo Horizonte, Editora UFMG.

VIANNA, Sergio Besserman. (1990), "Duas tentativas de estabilização”, in M. P. ABREU (org.), A ordem do progresso: cem anos de politica econômica republicana. Rio de Janeiro, Campus. 


\section{A ECONOMIA POLÍTICA DOS BACHARÉIS UDENISTAS}

\section{Jorge Gomes de Souza Chaloub}

Palavras-chave: Bacharéis; UDN; Economia; Afonso Arinos; Aliomar Baleeiro; Bilac Pinto.

O presente artigo expóe as concepçóes de economia dos principais bacharéis udenistas, tais como Afonso Arinos, Aliomar Baleeiro e Bilac Pinto. Distintamente da consagrada tese de Maria Victoria Benevides, que vê nos bacharéis um discurso econômico arcaico e vago, o texto identifica uma concepção relativamente estável da economia, compreendendo-a como atravessada por imposiçóes de ordem política e jurídica. Não se está diante da ausência de reflexóes, mas de uma perspectiva politizada da economia, coerente com o tipo de liberalismo defendido por tais atores, que conferem ao direito, e não ao mercado, o protagonismo na ordenação do mundo social. O texto também demonstra como os bacharéis não ignoravam os debates da teoria econômica contemporânea, mesmo que se vinculassem a outra tradição política. A proximidade com as questóes da época, não passava, todavia, pela recusa ao passado, mas decorria da atualização de certas tradiçóes, como a centralidade estatal, há pouco em descrédito.

\section{THE POLITICAL ECONOMY OF UDN'S JURISTS}

Jorge Gomes de Souza Chaloub

Keywords: Jurists; UDN; Economy; Afonso Arinos; Aliomar Baleeiro; Bilac Pinto.

This article exposes the economic views of the main jurists of the political party UDN (União Democrática Nacional - National Democratic Union), such as Afonso Arinos, Aliomar Baleeiro and Bilac Pinto. Maria Victoria Benevides' thesis sees in these actors an archaic and vague economic discourse. On the other hand, this text identifies on them a relatively stable conception of economics crossed by impositions of political and legal order. They had rather more a politicized view of the economy, coherent with the kind of liberalism advocated by such actors, than an absence of reflection on the field. For these UDN jurists, the leading role in the ordering of the social world belongs to the Law, not to the market. This article also shows that these jurists did not ignore their contemporary economic theory, but that they belonged to a different political tradition. Their proximity to the main issues of the period did not mean a denial of the past, but the actualization of certain traditions, such as the centrality of the state, lately in discredit.

\section{L'ECONOMIE POLITIQUE DES DIPLOMES LIES A L'UNION DEMOCRATIQUE NATIONALE (UDN)}

\author{
Jorge Gomes de Souza Chaloub
}

Mots-clés: Diplômés; UDN; Économie; Afonso Arinos; Aliomar Baleeiro; Bilac Pinto.

Cet article présente les conceptions de l'économie des principaux diplômés liés au parti de l'Union Démocratique Nationale (UDN), tels qu'Afonso Arinos, Aliomar Baleeiro et Bilac Pinto. Contrairement à l'excellente thèse de Maria Victoria Benevides qui considère que les diplômés ont un discours économique archaïque et vague, le texte identifie une conception relativement stable de l'économie. Il la considère comme traversée par des contraintes d'ordre politique et juridique. Nous ne sommes pas face à une absence de réflexions, mais à une perspective politisée de l'économie, cohérente avec le genre de libéralisme défendu par ces acteurs qui conferent au droit, et non pas au marché, le rôle protagoniste dans la mise en ordre du monde social. Le texte démontre également que les anciens étudiants n'ignoraient pas les débats de la théorie économique contemporaine, même s'ils s'attachaient à une autre tradition politique. La proximité avec les enjeux de l'époque ne passait pas, néanmoins, par le refus du passé, mais découlait de la modernisation de certaines traditions, comme la centralité étatique, en discrédit il y a peu de temps. 